\title{
On Philosophical Style
}

\section{Michèle Le Douff and Luce Irigaray}

\author{
Virpi Lehtinen
}

UNIVERSITY OF HELSINKI

ABSTRACT Irigaray and Le Dœuff diagnose the problem of woman and philosophy in terms of love. The differing solutions to the problem can be found in their styles. Irigaray's style is loving and dialogic, transforming the inherent structure of love and reminding us of the traditional feminine position defined by men. Le Douff's style is critical and pluralistic and relates to her perception of the feminine way of philosophical writing. These styles take into account the undervaluation of the feminine in the apparently 'neutral' practices of philosophizing and surpass the traditional or unreflected notions of the feminine style. Ultimately, the consciously 'subjective' styles, with the inherent aims of self-reflectivity and openness for other persons and texts, prove necessary when striving for truth and objectivity. Thus, Le Dœuff and Irigaray question the standard notion of philosophical style as neutral 'non-style'.

KEY WORDS affectivity $\bullet$ couple $\bullet$ Irigaray $\bullet$ Le Douff $\bullet$ love $\bullet$ Sartre $\bullet$ sexual difference $\bullet$ style $\bullet$ wisdom $\bullet$ woman

In an interview, philosopher and novelist Iris Murdoch states: 'I am tempted to say that there is an ideal philosophical style which has a special unambiguous plainness and hardness about it, an austere, unselfish candid style.' Iris Murdoch continues: 'The literary writer deliberately leaves a space for his reader to play in. The philosopher must not leave any space' (Murdoch, 1999: 4-5).

According to Murdoch's ideal of philosophy, its universal requirements of argumentation and conceptual clarity, there is no remarkable variation in philosophical style, either individual or historical. Murdoch interestingly points out the indispensability of style for all, even philosophical, speech and writing, but attributes one specific style to philosophical enterprises. I argue, however, that philosophy also allows, even demands, stylistic variation. To this end, I examine the works of two philosophers, who encourage us both to reflect on our philosophical styles and to pose the question of sexual difference. 


\section{SEXUAL DIFFERENCE}

I take as examples the styles of Michèle Le Dœuff's (1989) L'Étude et le rouet and Luce Irigaray's (1984) L'Éthique de la différence sexuelle. These works are exemplary in two senses. First, they extend the standard concept of philosophical style explicitly both by arguing for its crucial importance and by putting it into operation. Second, their styles are motivated by a shared problem of thinking and writing as a woman philosopher. The problem arises from the fact that the canon of philosophy is composed of texts written by male philosophers. Furthermore, the fundamental philosophical practices have been formed and reformed by one sex only. Although women have studied philosophical questions and written philosophical works, these writings are not part of the philosophical canon, nor are sexuality or sexual difference included as themes.

However, there is one particular theme that links both philosophy and sexual difference: love. Love plays a role in philosophical practices, as Plato discussed in Symposium and Faidros. Also, Le Dœuff and Irigaray connect themselves with the philosophical tradition by focusing on love: both diagnose the problem of women and philosophy in terms of love. I argue that Irigaray's and Le Dœuff's problematizations of the interconnection of love, sexual difference and wisdom provide the background against which their philosophical styles can be identified and understood.

I study Irigaray's and Le Dœuff's philosophical styles in three interconnected dimensions: the constitution of the philosophical self and its relation to itself, the relationship to other philosophers and the philosophical tradition, and, finally, the relationship between self and other. Thus, in this context style is understood as an existential notion indicating the modes of being of the subject and its relations, not as a literary or linguistic concept. With regard to scientific work, style refers to the whole of scientific activity, including ways of posing questions, applying and choosing methods, constructing interpretations and presenting the process of research in writing. Despite its individuality, style is not created or voluntarily chosen by the subject. Rather, it is assumed in shared practices and ideals. The individual style repeats shared practices and ideals but also transforms them in actively revivifying them (Goto, 2004: 101, 112-15; Heinämaa, 2003: 31-44; Stein, 1989: 115).

\section{LISTEN, I ADDRESS YOU: L'ÉTHIQUE DE LA DIFFÉRENCE SEXUELLE}

Irigaray's L'Éthique de la différence sexuelle is composed of essays and essayist commentaries on classical and contemporary philosophical texts, in which she discusses Plato's notion of eros, Aristotle's category of place, 
Spinoza's notion of God, Descartes' passion of wonder, Merleau-Ponty's concept of chiasm and Lévinas's phenomenology of eros. The variety of chosen topics does not remind one of any standard composition of crucial philosophical themes. Even more extraordinary is the structure of the work. In addition to essays that do not comment on any particular philosopher, it is composed of three couples of philosophical contemporaries: Plato and Aristotle, Descartes and Spinoza, Merleau-Ponty and Lévinas. In these couples the successor can be seen as a critic and a reverser of the predecessor's philosophy. The relationship of reversion is affirmed by the philosophical canon with regard to the presentation of these couples in the works on the history of philosophy, in the commentaries and in encyclopaedias. Irigaray, however, does not want to belong to this chain of predecessors. This she shows, among other things, by focusing on certain topics and by formulating her critical comments.

Irigaray does not take as a starting point - not even in the mode of critique any one philosophy. She addresses a singular 'you', a person and a philosopher at one time, but discusses with several philosophers in the temporal continuum of the work. She does not operate from an 'impartial' third-person perspective or report discussions of other people, thus speaking with, at least seemingly, unquestionable and 'neutral' authority. She does not abstract from her own experience to construe a theory of the universal features of experience in general or to discover the ultimate reality. Rather, Irigaray keeps her discourse open both to her own experience, the experience of the reader and strives for a more general level of the (feminine) experience. If we study closely the structure of L'Éthique de la différence sexuelle it is possible to identify several dialogues, several levels, which refer to one another.

First, Irigaray's commentaries on the texts of classical and contemporary philosophers form dialogues focusing on specific topics. Second, the reader is invited to enter into a dialogue with the philosophical subject 'Luce Irigaray' constituting itself both in these dialogues and in the essays preceding and following them.

The texts discussed are named but Irigaray's position with respect to them is not clearly critical or constructive, instead, it is either both or wavers between the two. Irigaray's way of posing questions to the text, suggesting answers and abstaining from closing the discussion further constitutes a special relationship to the original texts and to the writers. It is often difficult to see where the source text ends and Irigaray's commentary begins. In this way, the reader is also invited to take a first-person look at the original texts that Irigaray comments on in order to find out his or her own position in relation to them, and, also, to identify Irigaray's voice more clearly. Thus, the third dialogic couple is formed of the male philosopher and the actual reader.

As the reader is invited to form her own conception of the original text as well as Irigaray's approach to it, the specificity of Irigaray's methodology 
and variety of topics becomes clearer. The reader is able to form a new beginning for her own philosophizing, and to relate herself both to the tradition and to Irigaray's way of opening it up. The fourth dialogue between the reader and Irigaray, now given from a new perspective, is formed. The fourth dialogue, on the one hand, presupposes that the reader has taken an analogous path to Irigaray in her work, although from the reader's own starting points. This common voyage, in the end, offers an opportunity to use this work, enabling the possibility of distinguishing oneself, or of defining one's own position, with regard to the tradition and with regard to the Irigarayan point of view that challenges it. By the multilayered dialogues, the reader is invited into an analogous process of self-reflection, which has been effectuated by the writer. As the materials studied are canonical philosophical writings, the self-reflection happens with regard to the philosophical tradition. Thus, the self-reflection discloses our inheritance in the thinking, presupposed in all scientific work. It also demonstrates new, possible modes of engaging or distancing oneself from the tradition of inherited thought.

\section{PASSIONATE STYLE}

Irigaray's style in L'Éthique de la différence sexuelle is extraordinary, especially so if we share the ideal of philosophical style articulated by Murdoch. Irigaray's style is not plain, straightforward or neutral. Rather, it is moving, passionate and poetic. Irigaray's style is questioning and fragmentary but still identifiable. These features together form an atmosphere of informality and intimacy, which is enforced by the conversational, rather than argumentative or exegetic, manner of discussion. Irigaray does not offer a scholarly interpretation with definite conclusions but engages herself in a dialogue with the texts and their writers as well as with the reader. In this intimacy, 'you', the lover addressed, is entwined with the reflective 'I' of both the reader and the philosopher addressed. This suggests that the lover of wisdom - the philosopher or the reader and the 'you' of intimacy, have something in common.

First, in sharing the same tradition, the unquestioned prejudices and unmapped possibilities might be the same for the philosopher and the reader of Irigaray's text, as the inheritor of the tradition. This suggests that the self-evident notions that need to be questioned lie deep in our tradition of thought. They are crystallized in the philosophical discourse but are spread throughout our thought in general.

Second, in connection with the passionate and poetic characteristics is the often emphasized feature that Irigaray's writing affects not only other texts but also us as readers of these texts. Accordingly, she characterizes her style as 'a double style', containing both the aspect of lovers' 
discourse and the aspect of exposition of thoughts (Irigaray, 1987: 191; see Heinämaa, 2001: 36; Vasseleu, 1998: 15).

Why then does Irigaray develop this double style? Why bring the language of intimacy into the sphere of philosophy, which is considered a public discourse par excellence in its claims for objectivity? To answer these questions, I study more closely Irigaray's articulation of the problem of woman and philosophy and her task setting.

\section{PROBLEM AND TASK}

In the first essay of L'Éthique de la différence sexuelle, Irigaray defines the task of a woman philosopher as follows:

I search for myself, as if I had been assimilated into maleness. I ought to reconstitute myself on the basis of disassimilation. Rise again on the basis of a culture, of works already produced by the other. Searching through what is in them - for what is not there. What allowed them to be, for what is not there. The conditions of possibility, for what is not there. Woman ought to be able to find herself, among other things, through the images of herself already deposited in history and the conditions of production of the works of man, and not on the basis of his work, his genealogy. (Irigaray, 1993: 9-10; 1984: 17; see also Irigaray, 1982: 7)

Here Irigaray argues that the search for 'the meaning of existing as a woman' must start from a situation in which woman is already found and known (Chanter, 1995: 44; Heinämaa, 1996: 172).

Irigaray argues that the essential features of woman's situation can be traced from traditional philosophical texts. In this written tradition, the role of a woman is to support the male philosopher and his projects as the wife, daughter or mother. Such characters have personal relationships with the philosopher and function as resources for the philosopher and his philosophizing. They do not have voices of their own, either as women or as philosophers (Irigaray, 1977: 147-8; 1982: 110; cf. Le Dœuff, 1989: 28, 118; Shapiro, 2002: 197-200). The presumption is that in the sphere of private intimacy, in affective and/or sexual relationships, no words are needed (Irigaray, 1982: 110). Thus, speech and writing are separated from sensibility and affectivity. Sensibility and affectivity, for their part, are associated with femininity rather than with neutrality or masculinity (which, for Irigaray, are one and the same thing) and speech and writing capable of reflecting these dimensions of subjectivity are not developed.

Understood in this way, woman's position is defined by and through man. Woman has no voice of her own, and man speaks for her in the sphere of the intersubjective without addressing her as a member of that sphere or without speaking with her in that sphere. If the position from which to speak 
is understood as a condition for the constitution of responsible, ethical subjectivity (Irigaray, 1987: 184), the consequences of woman's silence are serious: without the possibility of speech, no relation between two subjects - and thus no ethics - is possible. In the lack of interaction in speech and writing, the 'intersubjective' relation between man and woman is a relation of a male subject to a feminine other presented as an object or material. However, even if women and femininity in the sphere of the intersubjective are presented by men as the material or object of desire or love, this does not mean that women in themselves are incapable of speech and writing.

\section{LOVE RECONSIDERED: DOUBLE STYLE IN OPERATION}

I suggest that by her intimate and interrogative style Irigaray exposes the traditional relation of a woman to philosophy either as an object of love or desire or as a condition of possibility for masculine subjectivity, strictly distinguished from the activities of thought and meaningful speech. She gives us descriptions of the body both as it is lived by women, and in encounters with the sexual other, beginning from the elemental affective and sensible dimensions of subjectivity. Thus she forms a new point of view in the discussion of love and desire. This occurs on two levels. Irigaray expresses these emotions in her own right and in her own way. Thus she both creates an alternative to the earlier articulations of desire and love, and studies and questions the articulations insofar as they are descriptions of women without relying on the point of view of woman. The female position, as defined by man, is changed by woman becoming a subject of her own love and desire (Irigaray, 1987: 193, 194).

Second, when Irigaray takes this topic of woman's position and connects it to philosophical ideas of truth and wisdom, she changes the situation of woman in philosophy. This, for its part, leads to another transformation: the female speech position is transformed into a specific mode of philosophizing, a way of speaking through love about wisdom and truth. The female lover takes the position of a responsible subject by becoming capable of speech and writing. The transformation from an object or resource with no identifiable style to a responsible speaking subject is effectuated by the double style of amorous writing.

This model of philosophizing - loving wisdom - does not extract from thought and ethics the subject's affectivity and sensibility. Rather affectivity and sensibility are perceived as indispensable for theoretical activity. Thus, they have to be taken up and studied, both as the themes and as the ways of relating to other texts and persons. In this way, we can become conscious of the multidimensionality of our relationships and be able to cultivate these relations. In order to effect a change in the value-hierarchy between reason and passion and to create a new mode of relationship sexual difference - Irigaray argues that sensibility, passivity and affectivity 
are indispensable elements of subjectivity in both its modes: feminine and masculine. She suggests that the condition for the possibility of the relationship of two subjects is in our capacity to be touched and moved by an other who is sexually different from us. Such a touching and moving can also happen through words and writing (Irigaray, 1987: 195; 1977: 76).

The textual couples effectuated by Irigaray can become a source for new dialogues and new ways of questioning. But there is still more to this style than the mere aim of showing the possibility of a philosophical dialogue between a female and a male philosopher through writing. Irigaray advocates the dialogic model of philosophizing in general and argues that sexual difference is indispensable for a genuine dialogue regulated by the idea of truth. She demands that we scrutinize the impact of the idea of sexual difference in our ways of thinking. This impact can be studied only if the dialogue is actualized between a woman and a man: neither of the two is capable of sorting it out alone.

It is the problem of sexual difference that leads Irigaray to reject the idea of an impartial philosopher able to extract the most general features of our subjectivity alone by solitary reflection. She does this by opening a space between two perspectives, male and female, and demands that this space or tension is opened or effectuated and maintained especially in philosophizing. This inherent aim can be found in two passions, which are methodologically crucial in Éthique: Plato's eros and Descartes' wonder (see Heinämaa, 2001: 32-9; Songe-Moller, 1997: 23-36; Lehtinen, 2000: 213-38).

\section{WAS BORN EVERYWHERE: L'ÉTUDE ET LE ROUET}

In her early article published in L'Imaginaire philosophique as 'Cheveux longues, idées courtes ${ }^{1}$ Michèle Le Dœuff diagnoses the same asymmetry in the man-woman relationship, which is the starting point of Irigaray's critique of philosophy. Le Dœuff's diagnosis relies on her enquiries into the works, textual documents and lives of women who have philosophized and their status in philosophical societies and institutions. For Le Dœuff, the connection between the asymmetry of the positions of man and woman in philosophy and philosophical style occurs upon two occasions. These are the initiation into the philosophical and the idea of philosophical originality correlating with the idea of the philosophical.

Le Dœuff states, following the famous Platonic dialogues Phaedra and Symposium, that the dyadic relationship necessarily belongs to philosophical didactics. This holds for both men and women. In both cases, the desire for philosophizing is directed or aroused by an admired teacher. Thus, like Irigaray, Le Dœuff also sees the entry to the philosophical as an affective process. However, the initial situation is different for the two sexes, so there are also two different ways to proceed. In one case, the pupil and the teacher are both male. At some stage of the process of 
initiation the other male teachers help, perhaps only by their presence, to question the mastery of the admired teacher. This enables the disappointment needed in philosophizing to occur. If the feeling of lack in this context never arises, the pupil has become a member in a philosophical school. However, this scheme departs from the dyadic phase, since usually there are also other pupils of one master, a relationship of one to many. (Le Dœuff, 1980b: 141, 142; see also Songe-Moller, 2002: 149-52).

In the case of women, the situation has been different. In the history of philosophy, access for women to the institutions of philosophizing has been rare. Nor have there been many female teachers. This has meant, first, that the didactic relationships have been private, without institutional support or constraint. Second, usually there has only been one master for the pupil, and, moreover, a master of the opposite sex. These features have factually led to amorous relationships. As the philosophical couples from different periods of time Le Dœuff lists, among others, Hipparchia and Crates, Princess Elizabeth and Descartes, Heloïse and Abelard and de Beauvoir and Sartre. Le Dœuff has invented the concept of theoretico-amorous transference (transfert érotico-théorique) to describe the asymmetry in access to philosophy. It is important to know that Le Dœuff's list does not include all the women philosophers of the past, not even those who have had an amorous relationship with a male philosopher. ${ }^{2}$

The problem of theoretico-amorous transference is, from the point of view of rigorous thought, the identification of the master and his philosophical ideas. This identification gives the illusion of a perfect philosophical system and a philosopher-master capable of answering all questions. In this kind of relationship, the experience of lack, according to Le Dœuff indispensable for philosophizing, never rises. In many known cases women's role has been to be a private pupil (and/or muse, beloved or, in the best case, a novelist) whereas men have occupied the position of master philosopher. This has led to the more general understanding of women being supporters of male philosophers rather than being philosophers in their own right. ${ }^{3}$ In such a setting, the philosopher's interest has not been in encouraging critical questions concerning his own thought or his system. In this scheme, neither men nor women become independent thinkers, since for an independent thinker no one philosophical system is enough, not even one's own. Autonomous thinking presupposes access to philosophy in general (Le Dœuff, 1980b: 141; 1989: 73).

Le Douff argues that such a confused identification is possible only because philosophical work and the philosophical person are contrasted to certain practices and characteristics associated with women. This identification is also visible in notions that rigidly separate philosophy from other modes of investigation. The problem has concerned both the self-understanding of the philosophers and the reception of their work by others. These roles have been further enforced by institutions and the processes of canonization. ${ }^{4}$ 
Le Dœuff also connects asymmetry to the time and place of her own thinking, writing and teaching by studying how the university institution and the philosophical community set criteria for philosophical independence and originality. Le Dœuff identifies two different styles of (philosophical) writing: masculine and feminine, usually corresponding to the sex of the writer. Le Dœuff claims to find these styles among anonymously written exams. The masculine style can be characterized as authoritative. It can lead either to 'decisive and profound reading' or to 'a fantastic misinterpretation'. The feminine style is receptive and attentive towards the texts. Examiners comment on examples of this style in phrases like: 'acuteness in detailed commentary but lack of overview'. According to Le Dœuff, this kind of approach can produce good results as it provides 'a distanced kind of reading which enables one to see what is implicit in the text or to pick out the "gaps" in theorization'. However, as Le Dœuff points out, this style is not highly valued. This is obvious both with regard to the evaluations of exams and to what is considered original in philosophical writings and ideas (Le Dœuff, 1980b: 161).

Le Dœuff suggests two possible explanations for the undervaluation. The first is that women fail in becoming philosophers, which means that they are polite to others' discourses, but do not develop a discourse of their own. The second option, which Le Dœuff herself prefers, is that this approach is underestimated because it is feminine and associated with lack of authority (Le Dœuff, 1980b: 162; cf. Irigaray, 1977: 76; 1987: 187; Heinämaa, 1997: 21-5). Nevertheless, philosophical genres can be found to which the so-called 'feminine' kind of style seems to belong more easily than to others. This style of writing seems to suit well the genre of writing commentaries, whereas it is not usually associated with original philosophical work (Le Dœuff, 1980b: 162).

Despite the similarities in the diagnosis of the problem of women and philosophy, the aims of Irigaray and Le Dœuff differ. Le Dœuff's aim is to deconstruct rather than transform the couple structure. Thus, Le Dœuff's position seems almost directly opposed to that of Irigaray. I argue, however, that there are, despite obvious differences, interesting connections and similarities between their projects. I do this by focusing on the common target of their critique: the phenomenological tradition and its account of the self-other relation, as exemplified in Sartre's work.

\section{THE WORK AND THE LETTER}

Sartre as an individual thinker and the phenomenological tradition as a whole share a methodological problem that is insurmountable from the pluralist point of view of Le Dœuff. This problem is the subject, the ego, as the starting point of the philosophical enterprise. This central methodical 
approach can be found in Sartre's ideas of values and morals, which are based on an abstraction of generic humanity, claims Le Dœuff. According to Le Dœuff, Sartre assumes on the fundamental ontological level that we cannot have intersubjective relations (Le Dœuff, 1989: 12, 213). Ultimately, on the basic level of being, the subject is freed from intersubjectivity, and as such she or he is free from all external constraints. Le Dœuff argues that this line of thought makes the Sartrean ethics of authenticity deeply problematic to feminism: it makes the analysis of oppression fundamentally obsolete, because of the emphasis on the ethical choices made by an autonomous individual $^{5}$ (Le Dœuff, 1980a: 3). Even though the emphasis on the responsibility of the subject for its acts is a promising idea, with respect to Sartre's philosophy this ideal fails, in practice, when we consider the (philosophical) style of Sartre. The exposure of his thought shows a tension with the crucial ethical doctrine of the subject as responsible for its acts.

Le Dœuff points out that the ego as an unquestioned starting point and end result is not only central in Sartre's ontological and ethical work, but is also operative in his posthumously published letters edited by de Beauvoir according to Sartre's wishes and titled Lettres au castor et à quelques autres (Sartre, 1983). Only some of de Beauvoir's own letters are included but other female correspondents are not included in the collection. This makes Sartre appear as the only speaking subject, capable of defining and redefining the relationship between himself and others. Ultimately, Le Dœuff argues, the question is about defining the meaning of himself and others insofar as they belonged to his world. Sartre does not allow himself to be questioned by others, neither does he offer them the possibility of presenting their views: the plurality of views and lived relations is silenced in favour of Sartre's (Le Dœuff, 1989: 204, 207). This is both on the account of the selection of the material, and the content of it. As a result, the subjectivity of correspondents is diminished. The private and partial discussions remain in the sphere of private intimacy despite the publication of the 'correspondence'. Accordingly, the position of the reader is given as that of a voyeur in this one-sided 'exchange', being unable to take part in the discussion or to break into the monologue. Le Dœuff suggests that in these writings - L'être et le néant and Lettres au castor - Sartre's solipsistic philosophy and his private life merge (Le Dœuff, 1989: 204, 207).

According to Le Dœuff, Sartre's approach in both cases creates an illusion of self-sufficiency. Le Dœuff challenges this self-sufficiency by showing that admiring women - not philosophers themselves, though sometimes knowledgeable about philosophy - are needed as mirrors for the ideas and passions of the speaking subject (Le Dœuff, 1989: 149). Women are integrated into the philosophical system as examples of bad faith and sexual bodies, but not as ideal or imaginary partners in the exchange of ideas or in the creation of concepts. So the main problem of Sartre's philosophical work is that the difference between women and 
men forms a conceptual resource in the construction of arguments, but neither this difference, nor other differences, are taken into account in the self-reflection of the (philosophizing) subject (Le Dœuff, 1989: 86-9).

It would, however, be a mistake to connect Sartre's approach to a way of philosophizing practised particularly by men (Le Dœuff, 1989: 105). Following the specification of Robin May Schott (2003: 28), this style can be identified as masculinist. It should also be noticed, that a feminist framework does not self-evidently save us from the problems of Sartre's philosophy diagnosed by Le Dœuff.

Although Le Dœuff's analysis of Sartre's work reminds one of Irigaray's notion of women as objects and as a resource for philosophizing, her critique of Irigaray's thought is sharp. Le Dœuff connects Irigaray to the existentialist tradition indirectly by taking up her idea in Ce sexe qui n'en est pas un (Irigaray, 1977) of philosophical discourse as a master's discourse that gives laws to the other discourses (Le Dœuff, 1980a: 2). Le Doueff thinks that the consequence of this privileged position of philosophizing is that the primary enemies are 'idealistic logic and metaphysical logos' (Le Dœuff, 1980a: 278; 1989: 2; see also Deutscher, 2002: 18; Whitford, 1991: 6). Since the critique of Irigaray is found within the same context as the critique of Sartre, it suggests that according to Le Dœuff also Irigaray's discourse is generalizing and abstract and is thus unable to grasp the concreteness of oppression.

The view on philosophical style presented by Murdoch is also criticized by Le Dœuff. Le Dœuff suspects that the philosophical enterprise aiming merely to clarify concepts might on closer scrutiny be revealed as valueladen (Le Dœuff, 1989: 44, 45). This is because, in believing in its own neutrality and pureness, this approach has forgotten the need to develop methods to enquire into its own way of philosophizing. ${ }^{6}$

As an alternative to the mode of exchange represented by Sartre, Le Doeuff proposes an attitude she calls 'the adventure of a message'. This means a written message directed towards another actual person, and not simply to an abstracted not-me (autrui) (Le Dœuff, 1989: 205). The message, by its nature as a message, exposes the sender as vulnerable: she or he might receive an unanticipated response. Although all expressed thoughts can be more or less freely interpreted by others, the difference lies in the attitude of the writer: the writer can either deny and minimize this freedom of others or he or she can accept and affect it, and even integrate this acceptance into the style of writing. The acceptance requires that the writer perceives him- or herself realistically, as a finite subject exposed to errors and self-deception. This would mean that the possible errors and imperfection would not be projected onto others. The attitude presupposes that the self is by some means able to distance itself from itself, for instance with the help of textual or concrete others. This idea can also be operative in philosophical work, and, it seems to me, that it works in this way in Le Douff's L'Étude et le rouet. 


\section{NOTEBOOK}

Le Dœuff's L'Étude et le rouet is written in the form of four notebooks. I argue in this final part of the article that the notebook form enacts Le Doeuff's understanding of philosophizing and its sexual dimensions and that this form is crucial to her way of both differentiating and connecting between philosophical ideas and persons without compromising the openness of the discussion.

Notebooks are usually written in the first person, but they are distinguished from diaries by their organization of topics rather than by the actually experienced life events of the author. Notebooks present the work of thought as it proceeds in time, and not as a ready-made result or as a task already completed. A treatise is usually connected to one discipline only, whereas notebooks are collections of different parts and pieces, containing seeds and arguments from different fields of thought, life, science, politics, culture, literature and history. A notebook can function as a starting point for an autobiography, ${ }^{7}$ but also for an argument or a treatise. Notebooks can bring together any material contributing to creative thinking and they preserve the paths of thought for a great variety of revisions.

A notebook does not directly address another subject. It is not written to anyone in particular: it would have been written anyway, even if no one read it. The relationship between the writer and the reader is established through topics and their connections. As such it does not carry subjective or sexual, affective elements in its style, at least not in the way of fulfilling other persons', or even traditions' expectations.

\section{WORKING TOWARDS POLYPHONY}

Based on the idea of notebooks explicated above, Le Dœuff states that her aim in L'Étude et le rouet is to work on subjectivity, both her own and her readers'. Le Dœuff describes her approach as 'wandering thought', 'methodological subjectivism' and 'adventurous rigorousness' (Le Dœuff, 1989: 15, 244; Björk, 2002: 293). She states that her self-reflection works through the use of irony and imagination, which allow us to take distance both from ourselves and from the self-evident conceptions inherited from the tradition (Le Dœuff, 1989: 50, 244).

Similarly, Le Dœuff warns us of the dangers of affirming the idea that women and men have their own discourse, own values or own access to knowledge (Le Dœuff, 1980b: 36; 1998: 10). This idea of difference enforced by several male philosophers connects women, affectivity and irrationality. It has led to a belittling of women's intellectual capacities and has been used as an argument in denying women the possibility of speaking for themselves in the sphere of speech and writing. Rather, in the spirit of Le Dœuff, we should ask to what extent these ideas still persist among ourselves, as 
the traditional idea of difference according to Le Dœuff is kept alive by the feminists of difference. ${ }^{8}$

Rather than being gentle or suggestive, 'feminine' in the traditional sense, Le Dœuff's style is straight to the point, ironic and polemic, it is sharp, mocking and challenging. Le Dœuff's distancing style is in line with her ideas of multilinearity and polygenesis of thought as well as her rejection of the dyad-model of philosophizing. The attempt to open plurality and to reject the traditional idea of difference in thought leads to the idea of rejecting the asymmetrical loving couple as the model of philosophizing. Instead, Le Doeuff advocates eros as the love of wisdom originating from lack and disappointment, and thus separating itself from love directed towards the persons (Le Dœuff, 1980b: 142, 143). She claims that this is necessary if we want to strengthen the position of women philosophers. In practice, this separation can be accomplished by encouraging women to work in peer groups and by opening institutions for women and thus gaining access to the objective knowledge (Le Dœuff, 1980b: 166; 1998: 13, 17). ${ }^{9}$ In this setting, philosophy could open itself to women without intermediation by male philosophers. Furthermore, this would have an effect on philosophizing in general.

Le Dœuff understands philosophy, at its best, as the task of critical thought within the philosophical community comprising several different subjects coming from different origins. Le Dœuff provides us with a model of a desire for philosophy, which orientates itself by problems but does not aim to complete a perfect whole, whether as an idea of accomplished wisdom or promises of salvation (Le Dœuff, 1989: 132, 197; cf. de Beauvoir, 1976: 32). By her stylistic choices, Le Dœuff acknowledges the impossibility of complete (self) knowledge, and shows that thinking should be open-ended and tentative (Le Dœuff, 1989: 18). According to Le Dœuff, it is precisely the ideas of truth and objectivity that require that we rethink the idea of the philosophical work as being incomplete by its very nature. To this end, the reader is required to keep 'the element of doubt' in operation. Le Dœuff invites the reader not only to question the philosophical tradition with her, but also to question Le Dœuff as well as ourselves.

Le Dœuff's style of writing fights against the scholarly habit of exegetic studies of the philosophical canon. It also questions our ideas of philosophical commentary and original philosophical work. It challenges us and offers us an opportunity to begin our thinking anew with the help of its openings and its spirit of radical questioning, not from an already determined foundation but from our own position. Thus, it concretely works towards polyphony.

\section{CONCLUSIONS: TWO FEMININE STYLES}

Irigaray and Le Dœuff share the idea of the existence of the feminine style. Both connect the feminine style and its underestimation to the amorous 
man-woman couple. However, their ways of interpreting and relating to this style differ.

Irigaray transforms the traditional idea of eros as shared into two mutually exclusive ways of loving either spiritually or carnally by offering us love and dialogue as models for philosophizing. She extends thinking to the levels of sensibility and affectivity, and thus to all relations. For Irigaray, love demands distancing from oneself and one's own interests, whether the other term of the relationship is a text, a speech or a person.

Le Dœuff thinks that affection for the other person belongs to the initial phase of philosophizing. It is important to recognize this situation in order to encourage the pupils to philosophical independence, and the pupils themselves in order to strive for it. The aim is to keep the persons and their ideas separate. We strive for truth, or even love or desire it, as concrete individuals, and are thus in need of self-reflection and criticism offered by the philosophical community.

The disagreement in the notions eros, feminine style and the idea of sexual difference should not obscure the fact that the styles of both Irigaray and Le Dœuff could be interpreted as feminine in their own contexts and according to their own ideals. As such they develop, in their own ways, the ideal of feminine style, and connect in distancing from the traditional notions of woman and feminine, as they are articulated by the male philosophers. In addition, both question our habitualities in practising philosophy and both examine the preconditions of objectivity. The outcome of both analyses is that without reconsidering the issue of sexual difference, objectivity cannot be achieved or even reached. The 'subjective' style of philosophizing is crucial: the philosophizing subject and its relations have to be perceived and studied, when striving for truth and objectivity. This aim does not allow a neutral philosophical style deciphering (marks of) subjectivity to be an ideal. For both Irigaray and Le Dœuff, such an ideal would prevent radical self-reflection, which forms the core of philosophy for both these thinkers.

Irigaray and Le Dœuff create, in their own ways and in their own styles, positions of subjectivity and authority that depart from the traditional models. Instead of offering us a feminist school, a possibility to become their followers or to challenge their doctrines by reversal, both Michèle Le Doeuff and Luce Irigaray demand that we work towards our own practices, styles and habits of thinking, experiment with new topics and pursue new directions with our questioning. They both demand that we acknowledge our own concrete starting points and surpass them. One of those starting points is our sexual identity. This means that the relationships between the reader and the author, self and other, must be transformed, and the notions of philosophical community, philosophy and its task must be rethought. Thus, by their styles, Le Dœuff and Irigaray criticize, recreate and respond 
to the tradition of philosophical writing that fails to address them as woman thinkers.

\section{NOTES}

I am grateful to Sara Heinämaa and Martina Reuter for their insightful and critical comments. I also wish to thank Luce Irigaray for generously commenting on the manuscript.

1. First published as 'Women and Philosophy' in Radical Philosophy 17 (Oxford, 1977).

2. It is interesting to compare the couples discussed by Le Dœuff with the case of Hannah Arendt and Martin Heidegger, Arendt's case differs from Le Dœuff's model: Arendt has become a philosopher both for herself and for the philosophical community. Following Le Dœuff's insights one could claim that her independence was saved by her philosophical as well as political disappointment in her teacher/lover. She first left Marburg to write her dissertation with Karl Jaspers in Heidelberg. Later, being a Jew, she had to leave Germany first for France and then for New York, where she created an intellectual community of her own (Arendt and Heidegger, 2004: 41, 42, 52, 53; Young-Brüehl, 1982: 42-110).

3. On the philosophical relationship of Descartes and Princess Elizabeth of Bohemia, see Le Douff (1980b: 137, 139; see also Alanen, 2004: 193-214; Reuter, 2000: 33-9; Shapiro, 2002: 199, 200). Philosophical style plays a crucial role in this discussion.

4. For a notion of a philosopher as a writer established in the de Beauvoir scholarship, see Heinämaa (2003: 1-18).

5. According to Le Dœuff (1980a), de Beauvoir was able to establish an existentialist ethics in which the idea of being responsible for one's acts and indifferences led to a fruitful analysis of women's oppression. Further evidence of the importance of de Beauvoir's philosophy for understanding the actual lives of women is offered by Heinämaa (2003: 132-3), who develops Beauvoirian phenomenology in analysing, for example, the experience of giving birth. Schott (2004: 93-114) applies de Beauvoir's ethics to articulate the specific kind of ethical failures of sexual war crimes.

6. For Le Dœuff's methodology developed in the context of analytic philosophy, see La Caze (2002).

7. For de Beauvoir on women, biography and literature, see, for example de Beauvoir (1976: 618). About autobiography and its connection to the feminine world, see also Irigaray (1987: 191). Both suggest that the feminine modes of surpassing a singular life of an individual - in other words, feminine subjectivity - are still to be created.

8. In L'Imaginaire philosophique, Irigaray as the writer of the Spéculum de l'autre femme figures as a critical feminist, but later as an uncritical feminist of difference (Le Dœuff, 1980b: 153; 1989: 132, 247-53; 1998: 118-19).

9. This is Le Dœuff's project in her latest book, Le Sexe du savoir. In this work Le Dœuff's interlocutors are, among others, the independent women philosophers of the past such as Christine de Pisan, Gabrielle Suchon and Anna Maria van Schurman. Thus, Le Dœuff also widens the circle of our peers, since these philosophers are not part of the official history of philosophy. Also Arendt figures here as a critic of totalitarian thought. 


\section{REFERENCES}

Alanen, Lilli (2004) 'Descartes ja Elizabeth - A Philosophical Dialogue', pp. 193-214 in L. Alanen and C. Witt (eds) Feminist Reflections on the History of Philosophy, New Synthese Historical Library Series, Vol. 55. Dordrecht, Boston and London: Kluwer.

Arendt, Hannah and Martin Heidegger (2004) Letters 1925-1975, ed. U. Ludz, trans. A. Shields. Orlando, FL: Harcourt, Inc. (Orig. pub. Briefe 1925-1975, ed. U. Ludz; Frankfurt am Main: Vittorio Klostermann, 1998.)

Björk, Ulrika (2002) 'Michèle Le Dœuffin haastattelu', trans. from English by V. Lehtinen and S. Heinämaa, Tiede E edistys 4(27): 293-303. (French translation 'Dialogue', Australian Journal of French Studies 3(XL), 2003: 351-63.)

Chanter, Tina (1995) Ethics of Eros: Luce Irigaray's Rewritings of the Philosophers. New York and London: Routledge.

De Beauvoir, Simone (1976) Le Déuxième Sexe I \& II. Paris: Gallimard. (Orig. pub. 1949.)

Deutscher, Penelope (2002) The Politics of Impossible Difference: The Later Work of Luce Irigaray. Ithaca, NY and London: Cornell University Press.

Goto, Hiroshi (2004) Der Begriff der Person in der Phänomenologie Edmund Husserl. Würzburg: Köningshausen und Neumann.

Heinämaa, Sara (1996) Ele, tyyli, sukupuoli. Helsinki: Gaudeamus.

Heinämaa, Sara (1997) 'Pinnan liikettä: Luce Irigarayn ajatus naisellisesta tyylistä', niin E näin 3: 21-6.

Heinämaa, Sara (2001) 'Filosofi - praktik och dialog', Filosofiskt tidskrift 2(22): 32-9.

Heinämaa, Sara (2003) Toward a Phenomenology of Sexual Difference: Husserl, Merleau-Ponty, Beauvoir. Lanham, MD: Rowman and Littlefield.

Irigaray, Luce (1977) Ce sexe qui n'en est pas un. Paris: Minuit. (English trans. This Sex Which is Not One, trans. Catherine Porter with Carolyn Burke; Ithaca, NY: Cornell University Press, 1985.)

Irigaray, Luce (1982) Passions élèmentaires. Paris: Minuit. (English trans. Elemental Passions, trans. J. Collie and J. Still; London: The Athlone Press, 1992.)

Irigaray, Luce (1984) L'Èthique de la différence sexuelle. Paris: Minuit.

Irigaray, Luce (1987) Sexes et paréntes. Paris: Minuit. (English trans. Sexes and Genealogies, trans. G.C. Gill; New York: Columbia University Press, 1993.)

Irigaray, Luce (1993) An Ethics of Sexual Difference [L'Èthique de la différence sexuelle], trans. C. Burke and G.C. Gill. Ithaca, NY: Cornell University Press.

La Caze, Marguerite (2002) The Analytic Imaginary. Ithaca, NY and London: Cornell University Press.

Le Dœuff, Michèle (1980a) 'Simone de Beauvoir and Existentialism', Feminist Studies 2(6): 245-77.

Le Dœuff, Michèle (1980b) Recherches sur l'imaginaire philosophique. Paris: Payot. (English trans. The Philosophical Imaginary, trans. C. Gordon, 1989.)

Le Dœuff, Michèle (1989) L'Étude et le rouet. Paris: Seuil. (English trans. Hipparchia's Choice, trans. T. Selous; Oxford and Cambridge, MA: Blackwell, 1991.)

Le Dœuff, Michèle (1998) Le Sexe du savoir. Paris: Aubier. (English trans. The Sex of Knowing, trans. K. Hamer and L. Code; New York and London: Routledge, 2003.)

Lehtinen, Virpi (2000) 'Luce lrigarayn filosofinen hanke: Etiikka, rakkaus ja naisellinen', pp. 213-38 in A. Anttonen, K. Lempiäinen and M. Liljeström (eds) Feministejä - Aikamme ajattelijoita. Tampere: Vastapaino.

Murdoch, Iris (1999) 'Literature and Philosophy: A Conversation with Bryan Magee', pp. 3-30 in P. Condradi (ed.) Existentialistics and Mystics: Writings on Philosophy and Literature. London: Penguin. 
Reuter, Martina (2000) Questions of the Body, Sexual Difference and Equality in Cartesian Philosophy. Helsinki: Yliopistopaino.

Sartre, Jean-Paul (1943) L'être et le néant: essai d'ontologie phénomenologique. Paris: Gallimard.

Sartre, Jean-Paul (1983) Lettres au castor et à quelques autres, 1926-1939, édition établie, présentée et annotée par Simone de Beauvoir. Paris: Gallimard.

Schott, Robin May (2003) Discovering Feminist Philosophy: Knowledge, Ethics, Politics. Lanham, MD: Rowman and Littlefield.

Shapiro, Lisa (2002) 'Princess Elisabeth and Descartes: The Union of Soul and Body and the Practice of Philosophy', pp. 182-203 in G. Lloyd (ed.) Feminism and History of Philosophy, Oxford Readings in Feminism. Oxford and New York: Oxford University Press.

Songe-Moller, Vigdis (1997) 'Luce Irigaray rakkaudesta ja ihmetyksestä', trans. from English by S. Heinämaa, pp. 23-36 in S. Heinämaa, M. Reuter and K. Saarikangas (eds) Ruumiin kuvia: subjektin ja sukupuolen muunnelmia. Helsinki: Gaudeamus.

Songe-Moller, Vigdis (2002) Philosophy without Women: The Birth of Sexism in Western Thought, trans. P. Cripps. New York and London: Continuum. (Orig. pub. Den greske drømmen on kvinnens overflødighet, Oslo: Cappelen akademisk forlag, 1999.)

Stein, Edith (1989) On the Problem of Empathy, The Collected Works of Edith Stein, 3rd rev. edn, trans. W. Stein. Washington, DC: ICS Publications. (Orig. pub. 1917.)

Vasseleu, Cathryn (1998) Textures of Light: Vision and Touch in Irigaray, Levinas and Merleau-Ponty, Warwick Studies in European Philosophy. New York and London: Routledge.

Whitford, Margaret (1991) Philosophy in the Feminine. New York and London: Routledge.

Young-Brüehl, Elisabeth (1982) Hannah Arendt: For Love of the World. New Haven, CT and London: Yale University Press.

Virpi Lehtinen works as a researcher at the Department of Philosophy, University of Helsinki and the Academy of Finland. Her ongoing doctoral work concerns Luce Irigaray's discourses on love with Plato, Sartre, Merleau-Ponty and Lévinas, and the importance of these discourses for positioning Irigaray's work in the field of feminist thought. Address: Department of Philosophy, PO Box 9 (Siltavuorenpenger 20A), 00014 University of Helsinki, Finland. [email: virpi.lehtinen@helsinki.fi] 